\title{
Soil water storage capacity under chronosequence of revegetation in Yanhe watershed on the Loess Plateau, China
}

\author{
Feng Jiao ${ }^{1,2^{*}}$, Zhong-Ming Wen ${ }^{1,2}$, Shao-Shan $\mathrm{An}^{1,2}$ \\ From 2010 International Conference on Combating Land Degradation in Agricultural Areas (ICCLD'10) \\ Zi'An City, PR China. 11-15 October 2010
}

\begin{abstract}
The relationship between vegetation and soil moisture deserves attention due to its scientific importance and practical applications. However, the effects of soil moisture on vegetation development and succession are poorly documented. Here we study soil water storage in Yanhe watershed at northern Shaanxi on five different land uses, namely shrubland, farmland, natural grassland, woodland, and artificial grassland, and in soil under restoration for 5 , 10, 15, 20 and 25. The results show that (1) soil water in soil 0-60 cm below ground is the highest in farmland, and lower in shrubland, artificial grassland, natural grassland and woodland; (2) soil water in artificial grassland and woodland decreases rapidly as the soil depth increases; whereas soil water in farmland, natural grassland, shrubland and woodland decreases; (3) soil water storage of farmland is greater than that of shrubland, artificial grassland, natural grassland and woodland; and (4) the vegetation succession in soil undergo restoration for different years on eroded soil results in a decrease in soil water storage.
\end{abstract}

\section{Introduction}

Soil water is one of the most important resources for sustaining vegetation growth in the semiarid area of the Loess Plateau in northwestern China [1,2]. Soil of the Loess Plateau develops from thick loess material with high water storage capacity $[3,4]$ of about $200-300 \mathrm{~mm}$ $\mathrm{m}^{-1}$ on average [5], so the soil water in the area functions as a reservoir regulating vegetation growth. This is the main reason why the ecosystem in this semiarid area has been sustained for thousands of years. However, evapotranspiration of many planted grasses of leguminous species, shrubs, and forests is beyond what precipitation can recharge [6-14], which restrains further growth of much planted vegetation [15].

Many studies on physiological plant ecology have been conducted focusing on the relationship between vegetation and soil water [16-22], but many aspects of vegetation and soil water remains unclear. The objective of the present

\footnotetext{
* Correspondence: Jiaof11@126.com

'Institute of Soil and Water Conservation, Northwest A\&F University, Yangling, Shaanxi, China

Full list of author information is available at the end of the article
}

study is to identify changes in soil moisture in five different land uses including shrubland, natural grassland, artificial grassland, farmland, and woodland, and changes in soil moisture and water storage after different restoration periods of plantations. The most popular natural grassland in the study area with vegetative chronosequence is also investigated to evaluate soil water storage on lands with different restoration times.

\section{Materials and methods}

\section{Study area}

The study area is located in the Yanhe watershed of the Loess Plateau at N36 $23^{\prime}-37^{\circ} 17^{\prime}$ and E108 ${ }^{\circ} 45^{\prime}-110^{\circ} 28^{\prime}$ in northern Shaanxi Province. An on-site ecology station has comprehensively managed this area for 25 years. The area is $287 \mathrm{~km}$ in length, and $7687 \mathrm{~km} 2$ in size. Ninety percent of the land is hilly, $3 \%$ is villages, rivers, and lakes, and only $7 \%$ is suitable for intensive agriculture. The study area has a sub-arid climate characterized by heavy seasonal rainfall with periodic local flooding and drought; the average annual rainfall at the experimental site is $497 \mathrm{~mm}$ (1970-2000, CV22\%) with distinct wet and

\section{SpringerOpen $^{\circ}$}

(C) 2013 Jiao et al.; licensee Springer This is an open access article distributed under the terms of the Creative Commons Attribution License (http://creativecommons.org/licenses/by/2.0), which permits unrestricted use, distribution, and reproduction in any medium, provided the original work is properly cited. 
dry seasons. The rainy season starts in July and ends in October, and rainfall in August accounts for 23\% of the annual precipitation. The annual reference evapotranspiration is approximately $1,000 \mathrm{~mm}$. Most of the lands are located at 900-1500 m altitude, closely dissected, and sharp-edged with very steep slopes (the slopes are 40\%). The topography, soil type, soil and land-use patterns of Yanhe watershed are very typical in the Loess Plateau. Land-use types include sloping land, terraces, orchards, woodland, shrubland, natural grassland, wasteland and others [23].

\section{Study approach and sampling design}

The chronosequence method was used because of a conversion history in this area. The management was similar to previous practices according to known cultivation climate, topography, and soil type. Soil samples were collected in August 2006. The soil samples were taken with a corer and dried at $105^{\circ} \mathrm{C}$ for $12 \mathrm{~h}$. Soil moisture was measured using the oven-drying method (Nanjing Institute of Soil Research, Chinese Academy of Sciences, 1980). Soil samples were taken at 10 different depths: 20, $40,60,80,100,120,140,160,180$ and $200 \mathrm{~cm}$ below ground with 5 replicates per vegetation community. At each location, the soil bulk densities of samples taken from 0-20, 20-40 and 40-60 cm below ground were measured using a $100-\mathrm{cm}^{3}$ cylinder, respectively.

Soil rehabilitation in relation to vegetative cover is commonly studied by monitoring changes in plants and soil along a vegetative chronosequence developed on similar soil under similar climates [16]. This chronological approach has been widely used in applied ecosystem researches [24] and is considered retrospective, because existing conditions are compared with known original conditions and treatments. Retrospective approach was used in this study because of the availability of adjacent vegetation communities established $5,10,15,20$ and 25 years ago on eroded soils with similar properties. These vegetation communities provided a time gradient of grass occupancy on similar sites. Changes in soil properties were measured by comparing sites of different ages. Five age series (5-, 10-, 15-, 20- and 25-year-old vegetation community) were found adjacent to the study area, and have undergone light livestock grazing in recent years. Within each community $(5,10,15,20$ and 25 year-old vegetation), five sampling sites were selected and samples were collected with five replicates. Also, five non-vegetated lands near the planted sites (farmland) were chosen as controls for the chronosequence.

\section{Data analysis}

Soil water storage (soil water quantity within a certain depth) was calculated based on soil moisture and soil bulk density. Soil water storage has been used as the key factor to evaluate soil moisture, because calculations based on soil volume eliminated the influence of soil depth [25].

Soil moisture analysis of variance (ANOVA) and correlation were carried out using the SPSS11.0 procedures for sites in different succession stages. Duncan's test $(\mathrm{p}<$ $0.05)$ was used to compare means of soil variables when the results of ANOVA were significant at $\mathrm{p}<0.05$.

\section{Calculation of soil water storage}

Soil water storage (soil water quantity within a certain depth) was calculated based on soil moisture and soil bulk density. Soil water storage has been used as the key factor to evaluate soil moisture, because calculations based on soil volume eliminated the influence of soil depth $(\mathrm{Hu}, 1992)$. Soil water storage $[S W S i(\mathrm{~mm})]$ for a given soil layer $i$ was calculated using the following formula:

$$
S W S i=0.1 \rho D i h i
$$

Where $\rho$ is soil moisture (\%), $D i$ is soil bulk density (g $\mathrm{cm}-3)$, and $h i$ is the depth of the layer $i(\mathrm{~cm})$.

In this research, soil water storage at $0-60 \mathrm{~cm}, 60-120 \mathrm{~cm}$ and 120-200 cm below ground were calculated according to formula (1). Total soil water storage at 0 to $200 \mathrm{~cm}$ below ground was calculated as the sum of the soil water storage at 0-60 cm, 60-120 cm and 120-200 cm below ground.

\section{Results and discussions}

\section{Soil moisture in different land uses}

In the surface layer $(0-60 \mathrm{~cm})$, soil moisture was the highest in farmland, followed by shrubland, artificial grassland, natural grassland and woodland (Table 1). Compared with that in farmland, soil moisture decreased in shrubland, artificial grassland, natural grassland and woodland by $18.50,21.53,24.38$, and $31.44 \%$, respectively. Same as in the surface layer, in the 60-120 cm layer, the soil moisture was the highest in farmland, followed by shrubland, artificial grassland, natural grassland and woodland. Soil moisture in the $60-120 \mathrm{~cm}$ layer in farmland, shrubland and artificial grassland were similar to that in the surface layer in these land uses. However, soil moisture in the $60-120 \mathrm{~cm}$ layer decreased in natural grassland and woodland by 5.83 and $16.64 \%$, respectively, when compared with that in the surface layer in these land uses (Table 1).

In the 120-200 cm layer, soil moisture was the highest in farmland, followed by shrubland, natural grassland, artificial grassland and woodland. Soil moisture in natural grassland and shrubland was similar, and soil moisture in artificial grassland and woodland was almost the same, which was lower than that in other land uses 
Table 1 Soil moisture and bulk density in different land-use patterns

\begin{tabular}{|c|c|c|c|c|c|c|c|}
\hline Item & Soil layer & & Farmland & Artificial grassland & Natural grassland & Woodland & Shrubland \\
\hline & $0-60(\mathrm{~cm})$ & Mean (\%) & $9.03 \pm 2.68$ & $7.43 \pm 2.50$ & $7.26 \pm 2.03$ & $6.87 \pm 1.93$ & $7.62 \pm 3.22$ \\
\hline & & CV & 0.30 & 0.34 & 0.28 & 0.28 & 0.42 \\
\hline \multirow[t]{6}{*}{ Land use } & $60-120(\mathrm{~cm})$ & Mean (\%) & $8.99 \pm 1.82$ & $7.23 \pm 2.23$ & $6.86 \pm 3.06$ & $5.89 \pm 1.44$ & $7.63 \pm 2.60$ \\
\hline & & CV & 0.20 & 0.31 & 0.45 & 0.24 & 0.34 \\
\hline & $120-200(\mathrm{~cm})$ & Mean (\%) & $8.97 \pm 1.46$ & $6.00 \pm 1.86$ & $7.00 \pm 3.34$ & $5.41 \pm 1.71$ & $7.13 \pm 2.24$ \\
\hline & & CV & 0.16 & 0.31 & 0.48 & 0.32 & 0.31 \\
\hline & $0-20(\mathrm{~cm})$ & Mean $\left(\mathrm{g} \cdot \mathrm{cm}^{-3}\right)$ & $1.28 \pm 0.06$ & $1.24 \pm 0.03$ & $1.32 \pm 0.07$ & $1.35 \pm 0.07$ & $1.27 \pm 0.11$ \\
\hline & & CV & 0.05 & 0.02 & 0.05 & 0.05 & 0.09 \\
\hline \multirow[t]{4}{*}{ Bulk density } & $20-40(\mathrm{~cm})$ & Mean $\left(\mathrm{g} \cdot \mathrm{cm}^{-3}\right)$ & $1.35 \pm 0.05$ & $1.34 \pm 0.09$ & $1.32 \pm 0.03$ & $1.37 \pm 0.07$ & $1.34 \pm 0.07$ \\
\hline & & CV & 0.04 & 0.07 & 0.03 & 0.05 & 0.05 \\
\hline & $40-60(\mathrm{~cm})$ & Mean $\left(\mathrm{g} \cdot \mathrm{cm}^{-3}\right)$ & $1.32 \pm 0.09$ & $1.46 \pm 0.08$ & $1.36 \pm 0.08$ & $1.37 \pm 0.05$ & $1.36 \pm 0.04$ \\
\hline & & $\mathrm{CV}$ & 0.07 & 0.06 & 0.06 & 0.04 & 0.03 \\
\hline
\end{tabular}

(Table 1). Soil moisture in the $120-200 \mathrm{~cm}$ layer in farmland, shrubland and natural grassland were similar to that in the surface layer in these land uses. However, soil moisture in the 120-200 cm layer decreased in artificial grassland and woodland by 23.83 and $26.99 \%$, respectively, when compared with that in the surface layer in these land uses (Table 1).

\section{Soil water storage in different land uses}

In the surface and the 60-120 cm layer, water storage in farmland soil was higher than that in other land uses (Table 2). Although some data obtained from farmland fluctuated because of farming or soil preparation. The overall soil water storage in farmland was higher than that in other land uses. Artificial grassland and shrubland soils had almost the same soil water storage. Natural grassland and woodland had low soil water storage. In the 120-200 cm layer, water storage in farmland soil was higher than that in other land uses (Table 2). Soil water storage in natural grassland was almost the same as that in shrubland. Woodland had the lowest soil water storage (Table 2). Similarly, in the 0-200 cm layer, farmland had the highest soil water storage, followed by shrubland and woodland (Table 2).

\section{Moisture and water storage in soil with different restoration time}

Five replicated soil samples were collected from six sites with the same restoration time of $5,10,15,20$ or
25 years, respectively. Also, five nonvegetated lands in the vicinity of the planted sites (farmland) were chosen as controls for the chronosequence. It was assumed that soil in sites with 5-, 10-, 15-, 20- or 25-years of restoration was initially similar to the farmland site (Table 3 ). After 5, 10, 15, 20 and 25 years of natural grass occupancy, vegetation succession resulted in a fluctuation of soil moisture in the eroded soils (Table 3). Soil moisture in the surface layer of farmland was $9.89 \%$. Soil moisture in 5-, 10-, 15-, 20-year-old grassland in the surface layer were $8.20 \%, 9.60 \%, 7.05 \%, 7.84 \%$, and $8.65 \%$, respectively. Soil water storage in the surface layer of farmland was $77.84 \mathrm{~mm}$. Soil water storage in 5-, 10-, 15-, 20-year-old grassland at the surface layer were 44.52 $\mathrm{mm}, 78.19 \mathrm{~mm}, 56.41 \mathrm{~mm}, 68.81 \mathrm{~mm}$, and $69.47 \mathrm{~mm}$, respectively (Table 4 ).

\section{Conclusion}

Land use has an obvious effect on soil moisture and soil water storage. Farmland has higher soil moisture than other land uses, although the latter are located on the slope rather than intra-gully alluvial land, which is mostly used as forestlands or orchards. In most cases, table land has sufficient levels of soil moisture, but after long period of cultivation, the land degrades year by year. Our results indicate that the establishment and development of vegetation succession on eroded soil result in significant degenerations of soil moisture and temporary soil water storage. With increased plantation age, it is possible to

Table 2 Soil water storage $(\mathrm{mm})$ under different land-use patterns (\%)

\begin{tabular}{cccccc}
\hline Land use & Samples & $\mathbf{0 - 6 0}(\mathbf{c m})$ & $\mathbf{6 0 - 1 2 0}(\mathbf{c m})$ & $\mathbf{1 2 0 - 2 0 0}(\mathbf{c m})$ \\
\hline Farmland & 5 & $71.11 \pm 21.01$ & $70.93 \pm 14.58$ & $94.16 \pm 13.69$ & $\mathbf{0}(\mathbf{c m})$ \\
Artificial grassland & 3 & $60.70 \pm 22.21$ & $63.88 \pm 21.66$ & $69.51 \pm 18.73$ \\
Natural grassland & 7 & $58.49 \pm 17.02$ & $56.54 \pm 27.07$ & $76.58 \pm 38.76$ \\
Woodland & 7 & $56.53 \pm 17.50$ & $48.38 \pm 11.81$ & $59.39 \pm 19.11$ \\
Shrubland & 5 & $60.69 \pm 26.79$ & $62.55 \pm 22.09$ & $77.90 \pm 25.48$ \\
\hline
\end{tabular}


Table 3 Moisture and bulk density of farmland soil with different restoration periods

\begin{tabular}{ccccccc}
\hline Restoration (years) & \multicolumn{3}{c}{ Soil moisture (\%) } & \multicolumn{3}{c}{ Bulk density (g·cm } \\
\cline { 2 - 6 } & $\mathbf{0 - 6 0}(\mathbf{c m})$ & $\mathbf{6 0 - 1 2 0}(\mathbf{c m})$ & $\mathbf{1 2 0 - 2 0 0}(\mathbf{c m})$ & $\mathbf{0 - 2 0}(\mathbf{c m})$ & $\mathbf{2 0 - 4 0}(\mathbf{c m})$ & $\mathbf{4 0 - 6 0}(\mathbf{c m})$ \\
\hline 25 & $8.65 \pm 2.61^{\mathrm{abcd}}$ & $7.78 \pm 3.07^{\mathrm{abcd}}$ & $7.03 \pm 1.97^{\mathrm{bcd}}$ & $1.26 \pm 0.08^{\mathrm{c}}$ & $1.38 \pm 0.14^{\mathrm{ab}}$ & $1.38 \pm 0.11^{\mathrm{ab}}$ \\
20 & $7.84 \pm 3.14^{\mathrm{abcd}}$ & $7.65 \pm 2.93^{\mathrm{abcd}}$ & $7.90 \pm 1.82^{\mathrm{abcd}}$ & $1.31 \pm 0.08^{\mathrm{abc}}$ & $1.39 \pm 0.10^{\mathrm{ab}}$ & $1.40 \pm 0.06^{\mathrm{a}}$ \\
15 & $7.05 \pm 1.31^{\mathrm{bcd}}$ & $6.94 \pm 1.60^{\mathrm{cd}}$ & $7.24 \pm 2.48^{\mathrm{bcd}}$ & $1.30 \pm 0.06^{\mathrm{bc}}$ & $1.32 \pm 0.07^{\mathrm{abc}}$ & $1.37 \pm 0.05^{\mathrm{ab}}$ \\
10 & $9.60 \pm 1.56^{\mathrm{ab}}$ & $8.74 \pm 0.99^{\mathrm{abcd}}$ & $6.47 \pm 0.71^{\mathrm{d}}$ & $1.31 \pm 0.09^{\mathrm{abc}}$ & $1.37 \pm 0.06^{\mathrm{ab}}$ & $1.39 \pm 0.04^{\mathrm{ab}}$ \\
5 & $8.20 \pm 2.28^{\mathrm{abcd}}$ & $8.12 \pm 2.38^{\mathrm{abcd}}$ & $9.00 \pm 1.83^{\mathrm{abcd}}$ & $1.33 \pm 0.04^{\mathrm{abc}}$ & $1.40 \pm 0.04^{\mathrm{ab}}$ & $1.38 \pm 0.04^{\mathrm{ab}}$ \\
0 & $9.89 \pm 1.83^{\mathrm{a}}$ & $9.60 \pm 1.17^{\mathrm{ab}}$ & $9.41 \pm 1.12^{\mathrm{abc}}$ & $1.27 \pm 0.06^{\mathrm{c}}$ & $1.35 \pm 0.05^{\mathrm{abc}}$ & $1.31 \pm 0.10^{\mathrm{abc}}$ \\
\hline
\end{tabular}

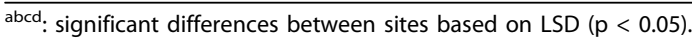

Table 4 Soil water storage $(\mathrm{mm})$ of farmland soil with different restoration periods

\begin{tabular}{|c|c|c|c|c|c|}
\hline Restoration (years) & Samples & $0-60(\mathrm{~cm})$ & $60-120(\mathrm{~cm})$ & $120-200(\mathrm{~cm})$ & $0-200(\mathrm{~cm})$ \\
\hline 25 & 5 & $69.47 \pm 22.34^{\mathrm{bc}}$ & $64.18 \pm 24.58^{\mathrm{cd}}$ & $77.77 \pm 22.38^{a b c}$ & $211.43 \pm 49.56^{a}$ \\
\hline 20 & 5 & $64.81 \pm 27.40^{\mathrm{bcd}}$ & $64.79 \pm 26.27^{b c d}$ & $88.93 \pm 22.42^{b c d}$ & $218.53 \pm 75.81^{a}$ \\
\hline 15 & 5 & $56.41 \pm 11.53^{\mathrm{cd}}$ & $56.94 \pm 13.33^{\mathrm{cd}}$ & $78.90 \pm 26.72^{a b c}$ & $192.26 \pm 36.45^{a}$ \\
\hline 10 & 5 & $78.19 \pm 12.62^{a b c}$ & $72.60 \pm 7.48^{b c}$ & $71.72 \pm 8.23^{b c}$ & $222.51 \pm 15.09^{a}$ \\
\hline 5 & 5 & $44.52 \pm 12.71^{d}$ & $67.58 \pm 21.52^{b c d}$ & $99.68 \pm 21.59^{a}$ & $211.79 \pm 53.83^{a}$ \\
\hline 0 & 5 & $77.84 \pm 14.55^{\mathrm{abc}}$ & $75.55 \pm 10.28^{a b c}$ & $98.39 \pm 10.02^{a}$ & $251.78 \pm 31.78^{a}$ \\
\hline
\end{tabular}

abcd. significant differences between sites based on LSD ( $p<0.05)$.

recover soil moisture and soil water storage to a certain degree.

\section{Competing interests}

The authors declare that they have no competing interests.

\section{Acknowledgements}

This study was sponsored by the Western Light Project of Chinese Academy of Sciences (2010y236), the National Natural Sciences Foundation of China (40871246), and Foundation for Youths Teacher by Northwest A\&F University.

\section{Declarations}

The publication costs for this article were funded by Scientific \& Technical Development Inc.

This article has been published as part of SpringerPlus Volume 2 Supplement 1, 2013: Proceedings of the 2010 International Conference on Combating Land Degradation in Agricultural Areas (ICCLD'10). The full contents of the supplement are available online at http://www.springerplus.com/ supplements/2/S1

\section{Authors' details}

${ }^{1}$ Institute of Soil and Water Conservation, Northwest A\&F University, Yangling, Shaanxi, China. ${ }^{2}$ Institute of Soil and Water Conservation, Chinese Academy of Science and Ministry of Water Resource, Yangling, Shaanxi, China.

\section{Published: 11 December 2013}

\section{References}

1. Li YS: The properties of water cycle in soil and their effect on water cycle for land in the Loess Region (in Chinese). Acta Ecol Sin 1983, 3(2):91-101.

2. Yang WZ, Han SF: Soil water ecological environment on the artificial wood land and grassland in Loess Hilly Region (in Chinese). Memoir NISWC, Academia Sin; 1985:2:18-28.

3. Wang $Z Q$, Liu BY, Wang $X Y$, et al: Soil water restoration of different land use after artificial forest in the semi-arid area of Loess Plateau (in Chinese). Trans Chin Soc Agric Eng 2007, 23(11):77-83.

4. Wang YP, Shao MA, Zhang XC: Soil moisture ecological environment of artificial vegetation on steep slope of Loess Region in north Shaanxi Province, China (in Chinese). Acta Ecol Sin 2008, 28(8):3769-3778.
5. Yang WZ, Shao MA: Study on Soil Water of Loess Plateau (in Chinese) Beijing: Science Press; 2000.

6. Li Y, Shao MA: Experimental study on influence factors of rainfall and infiltration under artificial grassland coverage (in Chinese). Trans Chin Soc Agric Eng 2007, 23(3):18-23.

7. Zhao YJ, Li J: Simulation of water productivity and soil desiccation of artificial Pinus Tabulae formis forestland on the Loess Plateau (in Chinese). J Northwest A F Univ 2007, 35(7):61-68.

8. Cheng JM, Wan HE, Wang J, et al: Growth of caragana korshinskii and depletion process of soil water in semi-arid region (in Chinese). Scie Silvae $\sin 2005,41(2): 37-41$.

9. Wang L, Shao MA, Zhang QF: Distribution and Characters of soil dry layer in north Shaanxi Loess Plateau (in Chinese). Chin J Appl Ecol 2004, 15(3):436-442.

10. Wang Li, Shao MA, Hou QC: Status of dried soil layer in the Yanan Experimental Area (in Chinese). Bull Soil Water Conserv 2000, 20(3):35-37.

11. Wang Zhiqiang, Liu Baoyuan, Lu Bingjun: A study on water restoration of dry soil layers in the semi-arid area of Loess Plateau[J]. Acta Ecologica Sinica 2003, 23(9):1944-1950.

12. Wang GL, Liu GB, Chang $X$, et al: A study on the effect of soil water on vegetation rehabilitation in watershed of Loess Hilly Area (in Chinese). J Nat Resour 2002, 17(3):339-344.

13. Fan J, Shao MA, Hao MD, et al: Desiccation and nitrate accumulation accumulation of apple orchard soil on the Weibei Dryland (in Chinese). Chin J Appl Ecol 2004, 15(7):1213-1216.

14. Chen HS, Shao MA, Li YY: Soil desiccation in the Loess Plateau of China Geoderma 2008, 143(1-2):91-100.

15. Wang $Z Q$, Liu BY, $X u C D$, et al: Survival capability of four artificial forests in the Loess Plateau (in Chinese). J Soil Water Conserv 2002, 16(4):25-29.

16. Bhojvaid PP, Timmer VR: Soil dynamics in an age sequence of Prosopis juliflora planted for sodic soil restoration in India. Forest Ecology and Management 1998, 106(2-3):181-193.

17. Hsiao TC: Plant responses to water stress. Ann Rev Plant Physiol 1973, 24:519-570.

18. Ingram J, Bartels D: The molecular basis of dehydration tolerance in plants. Ann Rev Plant Physiol Plant Mol Biol 1996, 47:377-403.

19. Lange OL, Kappen L, Schulze ED: Water and plant life: problems and modern approaches. Berlin: Springer; 1976.

20. Larcher W: Physiological plant ecology. Berlin: Springer; 31995.

21. Levitt J: Responses of plants to environmental stresses. New York: Academic Press; 2 1980l.

22. Nilsen ET, Orcutt DM: Physiology of plants under stress: abiotic factors New York: Wiley; 1998. 
23. Smith JAC, Griffith $\mathrm{H}$ : Water deficits: plant responses from cell to community Oxford, UK: Bios Scientific Pubulishers; 1993.

24. Yang WZ, Yu CZ: Region govern and evaluation in Loess Plateau[M] Beijing: Science Press; 1992, 45-69.

25. Fang W, SL Peng: Development of species diversity in the restoration process of establishing a tropical manmade forest ecosystem in China. Forest Ecology and Management 1997, 99(1-2):185-196.

26. Pedology (In Chinese). Yangling, Shaanxi: Tianze Press;Hu DY 1992:179-182.

doi:10.1186/2193-1801-2-S1-S15

Cite this article as: Jiao et al: Soil water storage capacity under chronosequence of revegetation in Yanhe watershed on the Loess

Plateau, China. SpringerPlus 2013 2(Suppl 1):S15.

\section{Submit your manuscript to a SpringerOpen ${ }^{\circ}$} journal and benefit from:

- Convenient online submission

- Rigorous peer review

- Immediate publication on acceptance

- Open access: articles freely available online

- High visibility within the field

- Retaining the copyright to your article

Submit your next manuscript at $\gg$ springeropen.com 